\title{
PEMANFAATAN IKAN RUCAH ZERO WASTE SEBAGAI PAKAN DALAM PEMELIHARAAN IKAN KUWE DI KERAMBA JARING APUNG DUSUN WAEL KABUPATEN SERAM BAGIAN BARAT
}

\author{
(The Utilization of Zero Waste Trash Fish as Feed Material for Trevally Fish \\ Cultured in The Floating Net Cage at Wael Village, Western Seram Regency)
}

\author{
Damaris Payung* dan Irawati \\ Program Studi Budidaya Ikan Politeknik Kelautan dan Perikanan Maluku \\ dpayung24@gmail.com,irawatimuhidin@gmail.com \\ Corresponding author*
}

\begin{abstract}
ABSTRAK: Pakan merupakan faktor yang sangat penting dalam menentukan keberhasilan suatu usaha budidaya. Salah satu jenis pakan yang digunakan dalam kegiatan budidaya ikan laut adalah ikan rucah. Tujuan penelitian ini adalah 1) mengetahui laju pertumbuhan ikan kuwe setelah pemberian pakan ikan rucah, 2) menganalisis konversi pakan serta efisiensi pemberikan pakan ikan rucah, dan 3) menganalisis tingkat kelangsungan hidup ikan kuwe dengan pemberian pakan ikan rucah di Dusun Wael, Kabupaten Seram Bagian Barat. Penelitian dilakukan pada bulan Mei-Nopember 2020 yang berlokasi di Dusun Wael Kawasan Minapolitan Kabupaten Seram Bagian Barat. Metode yang digunakan yaitu metode observasi melalui tahapan seleksi benih, pemeliharaan benih dan pemberian pakan. Keberhasilan pakan yang diberikan akan dianalisa melalui laju pertumbuhan ikan kuwe yang telah diberikan pakan, efisiensi pakan, konversi pakan serta kelangsungan hidup ikan kuwe. Hasil penelitian menunjukan laju pertumbuhan ikan kuwe sebesar 1,73\% dan tergolong baik. Hal ini dipengaruhi oleh padat tebar yang dilakukan sesuai dengan luas wadah dan kebutuhan ikan sehingga ikan kuwe dapat bertumbuh dengan baik. Nilai konversi pakan dan efisiensi pakan masing-masing sebesar 2,97 dan 33,3\%. Hasil konversi pakan dikategorikan masih layak bagi suatu usaha budidaya ikan kuwe. Kelangsungan hidup ikan kuwe sebesar 90-95\%, hal ini disebabkan karena manajemen pemberian pakan yang teratur, pengontrolan yang dilakukan setiap hari, serta padat tebar yang tidak terlalu tinggi.
\end{abstract}

Kata Kunci : Pakan, ikan rucah, konversi pakan, efisiensi pakan, Caranx sexfasciatus

ABSTRACT : Feed stands a significant factor in determining the success of a cultivation business. One type of feed used in marine fish farming is trash fish. The objectives of this study were 1) to determine the growth rate of trevally fish after feeding trash fish, 2) to analyze the feed conversion and efficiency of feeding trash fish, and 3) to analyze the survival rate of trevally fish by feeding trash fish in Wael Village, Westen Seram Regency. The research was conducted in May-November 2020, located in Wael Village, Minapolitan Region, Westen Seram Regency. The method used was the observation through the stages of seed selection, seed maintenance and feeding. The success of the feed given will be analyzed through the growth rates of trevally fishes that have been given feed, feed efficiency, feed conversion and survival rate of trevally fish. The results showed that the growth rate of trevally fish was $1.73 \%$ and it was classified as good. This is influenced by the stocking density which was carried out in accordance with the area of the container and the needs of the fish so that the trevally fish can grow well. The feed conversion values and feed efficiency were 2.97 and $33.3 \%$, respectively. The results of the feed conversion are 
categorized as still feasible for a trevally fish cultivation business. The survival of trevally fish is $90-95 \%$, this is due to the regular management of feeding, the daily control, as well as stocking density that is not too high.

Keywords: Feed, trash fish, feed conversion, feed efficiency, Caranx sexfasciatus

\section{PENDAHULUAN}

Kegiatan budidaya perikanan merupakan bentuk upaya konservasi yang dilakukan terhadap biota perairan dalam hal ini ikan (Nugroho, $d k k ., \quad 2012 ; \quad$ Syafei, 2017). Kementerian Kelautan dan Perikanan (KKP) menargetkan produksi perikanan budidaya untuk 2021 mencapai sekitar 19,47 juta ton, angka tersebut naik dari target produksi tahun 2020 sebanyak 18,44 juta ton (KKP, 2020). Salah satu program prioritas untuk mendukung kegiatan perikanan budidaya adalah program pakan mandiri yang diharapkan dengan pakan mandiri akan semakin strategis dan mampu meningkatkan produksi perikanan budidaya.

Pakan merupakan faktor yang sangat penting dalam menentukan keberhasilan suatu usaha budidaya (Agustono, dkk., 2009; Karimah, $d k k .$, 2018). Pakan berfungsi sebagai sumber energi utama bagi kelangsungan hidup dan pertumbuhan ikan. Biaya pakan dapat mencapai $60-70 \%$ dari total biaya produksi (Santoso\&Agusmansyah, 2011; Zakaria, dkk., 2018). Kenaikan harga pakan menyebabkan biaya produksi menjadi meningkat sehingga keuntungan menurun. Efisiensi dalam penentuan jenis dan frekuensi pemberian pakan yang sesuai kebutuhan akan memacu pertumbuhan dan perkembangan ikan secara optimal sehingga produktivitasnya bisa ditingkatkan. Salah satu jenis pakan mandiri yang sering digunakan dalam budidaya ikan laut di KJA adalah ikan rucah (Harahap, $d k k$., 2019). Ikan rucah (trash fish) merupakan surplus ikan hasil tangkapan atau sisa hasil pengolahan ikan, ikan rucah juga sering didefinisikan sebagai ikan yang tidak layak dikonsumsi oleh manusia karena penanganan yang kurang tepat atau tidak diolah sehingga tidak hieginis (Handajani, $d k k$., 2013).

Ikan Kuwe (Caranx sexfasciatus) di Maluku umumnya dibudidayakan dengan sistem budidaya Keramba Jaring Apung (KJA) (Mayunar, 1999; Baulu, dkk., 2017). Ikan Kuwe memiliki beberapa keunggulan antara lain tidak memerlukan perawatan yang terlalu intensif sebagaimana ikan kerapu (Epinephelus), tahan terhadap penyakit, mampu beradaptasi pada perubahan kualitas perairan yang ekstrim, memiliki pertubuhan yang relatif cepat karena konsumsi makanan yang banyak (Lumi, dkk., 2019). Keunggulan lain dari jenis ikan Kuwe dalam lingkungan budidaya selain memiliki pertumbuhan yang cepat juga efisien dalam memanfaatkan pakan serta mampu hidup dalam kondisi yang cukup padat.

Dusun Wael merupakan salah satu spot area budidaya yang ada di Kawasan Minapolitan Kabupaten Seram Bagian Barat. Daerah ini merupakan pusat budidaya ikan di keramba jaring apung. Pembudidaya pembesaran ikan kuwe di KJA Dusun Wael telah ada sejak tahun 2010. Pemanfaatan pakan rucah dalam kegiatan budidaya ikan kuwe ini tanpa adanya sisa limbah (zero waste). Ada dua keuntungan dari pemanfaatan pakan rucah dalam kegiatan pembesaran ini, pertama menekan biaya operasional dari $70 \%$ menjadi sekitar 40-50\%. Kedua, tidak adanya limbah yang terbuang sehingga tidak mencemari lingkungan perairan budidaya. Berdasarkan uraian tersebut maka tujuan penelitian ini adalah 1) mengetahui laju pertumbuhan ikan kuwe yang dibudidayakan setelah pemberian pakan ikan rucah, 2) menganalisis konversi pakan serta efisiensi pemberikan pakan ikan rucah, dan 3) menganalisis tingkat kelangsungan hidup ikan kuwe dengan pemberian pakan ikan rucah di Dusun Wael, Kabupaten Seram Bagian Barat.

\section{METODE PENELITIAN}

Kegiatan penelitian ini dilaksanakan pada bulan Mei hingga Nopember 2020 yang 
berlokasi di keramba jaring apung Dusun Wael Kawasan Minapolitan Kabupaten Seram Bagian Barat. Metode yang digunakan yaitu obervasi secara langsung melalui tahapan sebagai berikut:

\section{Seleksi Benih}

Seleksi benih dilakukan dengan memilih benih yang sehat, tidak cacat pada sirip maupun ekor, ukuran seragam, gerakan lincah, warna cerah, responsif terhadap makanan serta bebas penyakit. Benih yang digunakan yaitu ikan kuwe mata besar (Caranx sexfasciatus).

\section{Pemeliharaan Benih}

Pada awal penebaran benih dipelihara dalam keramba jaring apung dengan kepadatan 500 ekor per jaring $(3 \times 3 \times 3 \mathrm{~m})$. Ukuran mesh size dan kepadatan benih disesuaikan dengan ukuran benih. Keramba jaring apung dibersihkan satu bulan sekali. Disamping itu benih juga dibesarkan pada jaring yang berbentuk lingkaran. Ini dilakukan untuk melihat pengaruh pertumbuhan dengan bentuk jaring yang berbeda.

\section{Pemberian Pakan}

Selama pemeliharaan benih dilakukan pemberian pakan berupa ikan segar seperti ikan lemuru, ikan layang, kembung, teri dan sebagainya. Dosis pemberian pakan $5-10 \%$ dari berat total ikan dan diberikan 2 kali per hari (pagi hari jam 07:00 dan sore hari jam 16.30 WIT).

\section{Analisa Data}

Data yang telah diperoleh kemudian dianalisis berdasarkan parameter-paramater meliputi pertumbuhan, laju pertumbuhan, konversi pakan, efisiensi pakan serta kelangsungan hidup (survival rate).

\section{Pertumbuhan}

Pertumbuhan didefinisikan sebagai perubahan dimensi suatu organisme berupa berat atau panjang dalam waktu tertentu. Pengukuran pertumbuhan ikan uji dengan menghitung pertambahan berat biomassa dalam satu wadah, yaitu :

$$
\mathrm{W}=\mathrm{Wt}-\mathrm{Wo}_{\mathrm{o}}
$$

Ket:

$\mathrm{W}=$ Pertumbuhan biomassa mutlak ikan uji (g)
$\mathrm{W}_{\mathrm{t}}=$ Biomassa ikan uji pada akhir penelitian (g) $\mathrm{W}_{0}=$ Biomassa ikan uji pada awal penelitian $(\mathrm{g})$ Logaritma dari persamaan tersebut di atas merupakan regresi linier dimana "g" adalah koefisien arahnya. Jadi laju pertumbuhan "instantaneous growth (g)" didapat dari regresi linier persamaan berikut:

$$
\mathrm{Ln} \mathrm{W}_{\mathrm{t}}=\mathrm{Ln} \mathrm{W}_{0}+\mathrm{gt}
$$

$\mathrm{W}_{\mathrm{t}}=$ Biomassa ikan uji pada akhir penelitian

$\mathrm{W}_{0}=$ Biomasa ikan uji pada awal penelitian

$\mathrm{g}=$ Koefisien laju pertumbuhan

$\mathrm{t}=$ Lama penelitian

\section{Efesiensi Pakan}

Untuk menghitung efisiensi pakan, maka diperlukan informasi berat total ikan saat awal $\left(\mathrm{BT}_{0}\right)$, berat ikan setelah masa pemeliharaan tertentu $\left(\mathrm{BT}_{1}\right)$ dan jumah pakan yang habis setelah masa pemeliharaan tertentu $(\mathrm{P})$ dengan formula sebagai berikut:

$$
\text { Efisiensi Pakan }=\frac{B T_{1} \times B T_{0}}{P} \times 100 \%
$$

\section{Konversi Pakan}

Konversi pakan atau FCR (Feed Convertion Ratio) adalah jumlah (berat) pakan yang dapat membentuk suatu unit berat ikan. Adapun rumus untuk menghitung FCR adalah:

$$
\mathrm{FCR}=\frac{\text { Makanan yang dimakan }(\mathrm{g})}{\text { Pertambahan berat tubuh }(\mathrm{g})}
$$

\section{Kelangsungan Hidup (SR)}

Selama proses penelitian dilakukan pengamatan jumlah ikan kuwe yang mati dan jumlah ikan kuwe yang masih hidup, sehingga dapat dihitung persentase kematian dan kelangsungan hidup ikan kuwe dengan menggunakan rumus:

$$
\mathrm{S}=(1-\mathrm{Z}) \times 100
$$

Ket:

$$
\begin{aligned}
\mathrm{S}= & \text { Kelangsungan hidup }(\%) \\
\mathrm{Z}= & \text { Koefisien laju kematian, dihitung dengan } \\
& \text { rumus : In No-In Nt/t } \\
\mathrm{N}_{0}= & \text { Jumlah ikan kuwe yang hidup pada awal } \\
& \text { kegiatan } \\
\mathrm{N}_{\mathrm{t}}= & \begin{array}{l}
\text { Jumlah ikan kuwe selama periode } \\
\text { kegiatan }
\end{array} \\
\mathrm{T}= & \text { Waktu (minggu) }
\end{aligned}
$$




\section{HASIL DAN PEMBAHASAN}

Berdasarkan hasil penelitian, pola pertumbuhan (berat tubuh) ikan kuwe mengikuti pola sigmoid dimana pertumbuhan masih akan terus berkembang sampai pada titik pembelokan pertumbuhan mulai melambat (Gambar 1).

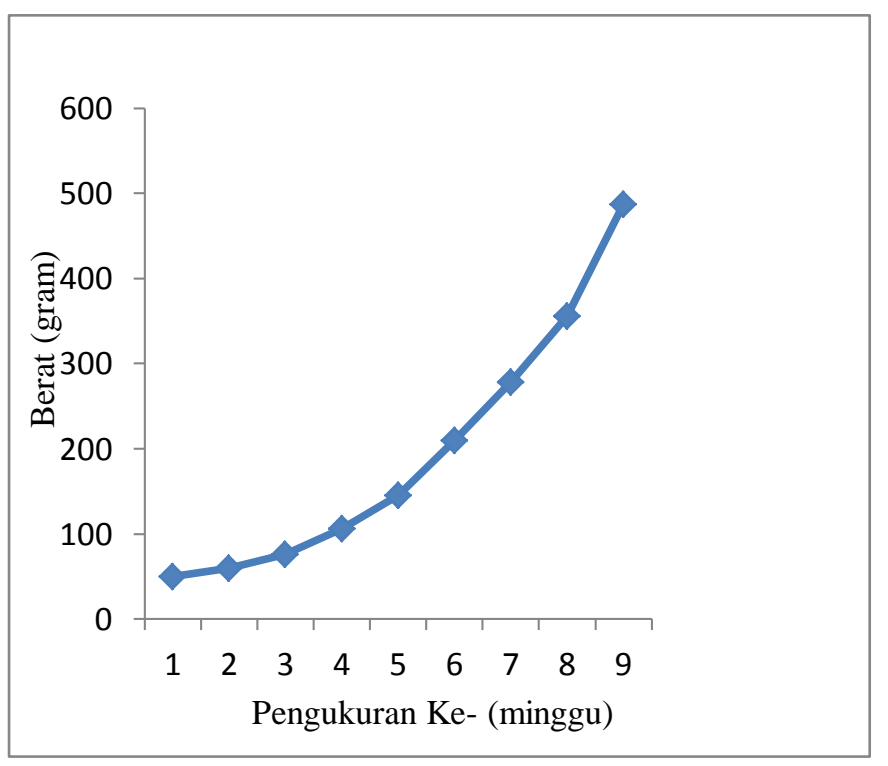

Gambar 1. Pola pertumbuhan ikan kuwe

Pertumbuhan merupakan rangkaian perubahan ukuran suatu organisme dapat berupa berat atau panjang dalam satuan waktu tertentu. Pola pertumbuhan terhadap pertambahan berat ikan kuwe terlihat bahwa menunjukan hasil yang agak lambat pada pengukuran minggu pertama hingga ketiga. Kemudian pertumbuhan ikan kuwe mengalami kenaikan pada pengkuran minggu keempat dan seterusnya. Lambatnya pertumbuhan yang terjadi diduga merupakan tahap adaptasi ikan kuwe terhadap lingkungannya yang baru setelah ikan diangkut dari tempat penampungan atau penangkapan oleh para nelayan ke tempat budidaya. Ikan dapat mengalami stress atau bahkan luka saat proses pengangkutan sehingga ikan membutuhkan waktu untuk dapat beradaptasi khususnya dalam pertumbuhannya (Yatiningsih, $d k k ., 2018)$. Transportasi benih ikan merupakan faktor penting dalam kegiatan budidaya. Tingkat kematian kegiatan budidaya dapat disebabkan juga oleh proses pengangkutan (Davis\&Griffin, 2004) yang dapat mengakibatkan stress pada ikan dan cedera fisik bahkan kematian. Perubahan kondisi lingkungan saat pengangkutan dapat menyebabkan ikan mengalami stress sehingga mempengaruhi kondisi fisiologis ikan (Ismi, 2017). Oleh karena itu perlu dilakukan domestikasi sehingga dihasilkan ikan yang sehat, mampu beradaptasi dengan lingkungan budidaya (Zulfadhli\&Fadhilah, 2019). Pada penelitian ini, sebelum dilakukan penebaran benih maka dilakukan penyortiran terlebih dahulu untuk memilih benih yang baik dan sehat.

Hasil penelitian menunjukan laju pertumbuhan berat ikan kuwe yang diberikan pakan dengan memanfaatkan semua limbah pakan sebesar $1,73 \%$. Hasil ini diduga disebabkan oleh padat tebar yang dilakukan sesuai dengan luas wadah dan kebutuhan ikan untuk dapat tumbuh dengan baik. Besarnya nilai laju pertumbuhan harian (LPH) tergantung jenis dan ukuran ikan yang ditebarkan (Hariyono, 2008). Hasil penelitian Rifai\&Horhoruw (2016) diperoleh rata-rata laju pertumbuhan harian ikan kerapu cantang 0,95\%/hari, ikan kerapu macan 0,85\%/hari dan ikan bubdara atau ikan kuwe 1,34\%/hari. Hariyano, dkk. (2008) memperoleh hasil laju pertumbuhan ikan kuwe berkisar antrara $1,11-1,13 \%$. Selanjutnya penelitian selanjutnya untuk ikan bubara memiliki laju pertumbuhan harian 0,90-1,71\%/hari (Hariyono, 2009). Penelitian laju pertumbuhan ikan bawal bintang (Trachinotus blochii) menunjukan hasil berkisar antara 0,78\%-1,40\%. Jika dibandingkan dengan hasil yang diperoleh dalam penelitian ini maka dapat dikatakan laju pertumbuhan ikan kuwe lebih baik dalam waktu pengamatan sembilan minggu. Hal ini diduga dipengaruhi oleh padat penebaran yang berbeda. Pada penelitian Hariyano, $d k k .$. (2008) dan Minjoyo, dkk.. (2007), penebaran benih masing-masing dengan kepadatan 100 ekor $/ \mathrm{m}^{3}$ jaring dan 70 ekor/ $\mathrm{m}^{3}$ jaring, sedangkan pada penelitian ini menggunakan kepadatan 64 ekor $/ \mathrm{m}^{3}$ jaring. Peningkatan padat penebaran yang tinggi akan mengganggu proses fisiologi dan tingkah laku ikan terhadap ruang gerak yang pada akhirnya dapat menurunkan kondisi kesehatan dan fisiologis ikan Azhari, $d k k .$, 2017). Akibat lanjut dari proses tersebut adalah penurunan pemanfaatan makanan, pertumbuhan dan kelangsungan hidup mengalami penurunan. 
Sedangkan jika terlalu rendah pemanfaatan ruang tidak maksimum dan produksi juga menurun. Padat penebaran benih ikan yang berlebihan bukan hanya menyebabkan kurangnya ruang gerak namun juga terjadi persaingan pakan, sehingga berpengaruh nyata terhadap pertumbuhannya (Raharjo, $d k k ., 2016)$.

\section{Konversi Pakan dan Efisiensi Pakan}

Konversi pakan yang diperoleh dalam penelitian ini adalah sebesar 2,97. Menurut Ghufron\&Kordi (2007) menyatakan bahwa konversi pakan ikan Kuwe berkisar antara 3-9. Penelitian konversi pakan telah dilakukan pada ikan gabus diperoleh nilai konversi berkisar antara 1,11-1,55 (Agustin, dkk., 2014). Hasil konversi pakan terhadap ikan bawal bintang diperoleh nilai berkisar antara 2,11-2,53 Saputra, dkk., 2018). Nilai konversi pakan menunjukan besarnya pakan yang dikonsumsi menjadi biomassa tubuh ikan. Hasil konversi pakan yang dihasilkan masih layak bagi suatu usaha budidaya ikan kuwe, sehingga dapat dianjurkan untuk dilakukan usaha pembesaran ikan kuwe karena masih menguntungkan. Artinya bahwa pakan ikan rucah (berupa ikan momar putih dan ikan belosoh) yang diberikan mempunyai kualitas yang baik, karena pakan tersebut dimanfaatkan dengan baik oleh ikan kuwe untuk pertumbuhan berat yang maksimal.

Kulitas pakan yang baik tidak hanya diketahui melalui nilai konversi pakan, tetapi juga dengan perhitungan efisinesi penggunaan pakan. Nilai efisiensi pakan diperoleh dari hasil perbandingan antara pertambahan bobot tubuh ikan dengan jumlah pakan yang dikonsumsi oleh ikan selama masa pemeliharaan. Semakin besar nilai efisiensi pakan, berarti semakin efisien ikan memanfaatkan pakan yang dikonsumsi untuk pertumbuhannya (Iskandar\&Elrifadah, 2015). Nilai efisiensi pakan yang diberikan pada ikan kuwe yaitu sebesar 33,3\%. Menurut Buwono (2000) dalam Sukoso (2002) efisiensi penggunaan makanan oleh ikan menunjukan nilai persentase makanan yang dapat dimanfaatkan oleh tubuh ikan. Jumlah dan kualitas makanan merupakan faktor penting yang diberikan kepada ikan berpengaruh terhadap pertumbuhan ikan. Pakan dalam jumlah sedikit akan menghambat pertumbuhan ikan, namun jika jumlah pakan terlalu banyak maka akan mengakibatkan kekeruhan air di keramba jaring apung.

\section{Kelangsungan hidup}

Kelangsungan hidup (SR) yaitu persentase jumlah benih ikan yang masih hidup setelah perlakuan. Hasil penelitian menunjukan kelangsungan hidup ikan kuwe setelah diberikan pakan sebesar 90-95\%. Kondisi tersebut didukung oleh manajemen pemberian pakan yang teratur, pengontrolan yang dilakukan setiap hari, serta padat tebar yang tidak terlalu tinggi. Kelulushidupan yang tinggi dikarenakan lingkungan media pemeliharaan ikan mendukung keberlangsungan hidup ikan salah satunya yaitu sistem sirkulasi (Karimah, dkk., 2018). Selanjutnya dikatakan, tinggi rendahnya kelangsung hidup ikan budidaya dipengaruhi oleh faktor abiotik dan biotik antara lain: kompetitor, kepadatan populasi, umur dan kemampuan organisme beradaptasi dengan lingkungan.

\section{KESIMPULAN DAN SARAN}

Berdasarkan hasil yang diperoleh, maka didapatkan beberapa kesimpulan sesuai tujuan yaitu sebagai berikut:

1. Laju pertumbuhan ikan kuwe menunjukkan nilai sebesar $1,73 \%$ dan tergolong baik.

2. Konversi pakan adalah 2,97 dan efisiensi penggunaan pakan adalah $33,3 \%$.

3. Tingkat kelangsungan hidup ikan kuwe untuk semua perlakuan adalah $90-95 \%$.

Memperhatikan hasil yang diperoleh dalam kegiatan ini, maka dapat disarankan bahwa pembesaran ikan kuwe di keramba jaring apung di spot budidaya Dusun Wael selama ini hanya mengandalkan benih dari alam, untuk itu perlu dilakukan usaha pembenihan sehingga usaha pembesaran yang terjadi di wilayah ini terus berlangsung.

\section{DAFTAR PUSATAKA}

Agustin, R., A.D. Sasanti, Yulisman. 2014. Konversi Pakan, Laju Pertumbuhan, kelangsungan Hidup dan Populasi Bakteri Benih Ikan Gabus (Channa striata) yang Diberi Pakan Dengan 
Penambahan Probiotik. Jurnal Akuakultur Rawa Indonesia 2(1): 55-66.

Agustono, W. Permata, Y. Cahyoko. 2009. Pemberian Pakan Dengan Energi yang Berbeda Terhadap Pertumbuhan Benih Ikan Kerapu tikus (Cromileptes altivelis). Jurnal Ilmiah Perikanan dan Kelautan 1(2): 149156.

Azhari, A., Z. A. Muchlisin, I. Dewiyanti. 2017. Pengaruh Padat Penebaran Terhadap Kelangsungan Hidup dan Pertumbuhan Benih Ikan Seurukan (Osteochilus Vittatus). Jurnal Ilmiah Mahasiswa Kelautan dan Perikanan Unsyiah 2(1): 12-19.

Baulu, A., L.M. Soukotta, D. Bawole. 2017. Manajemen dan Pendapatan Usaha Keramba Jaring Apung (KJA) di Negeri Amahai dan Kelurahan Lesane Kabupaten Maluku Tengah. Jurnal PAPALELE 1(2): 67-77.

Davis, B.K. and B.R. Griffin. 2004. Physiological Respon of Hybrid Striped Bass Under Sedatation by Several Anasthetics. Aquaculture, 233:531-548.

Ghufran.M \& Kordi K. 2007. Meramu Pakan Untuk Ikan Karnivor Baung, Belut, Betutu, Gabus, Jambal Siam, Kakap, Kerapu, Kuwe, Lele, Patin, Sidat, dan Toman. Penerbit Aneka Ilmu Semarang. ISBN 9789797366513248 hal.

Handajani, H., S.D. Hastuti, Sujono. 2013. Penggunaan Berbagai Asam Organik dan Bakteri Asam Laktat Terhadap Nilai Nutrisi Limbah Ikan. Depik 2(3): 126-132.

Harahap, A.F. R. Rostika, M.U.K. Agung, K. Haetami. 2019. Pemanfaatan Simplisia Pepaya pada Ikan Rucah untuk Pakan Kerapu Cantang (Epinephelus fuscoguttatuslanceolatus) di Keramba Jaring Apung Pesisir Pangandaran. Jurnal Perikanan dan Kelautan $\mathrm{X}(2)$ : 56-64.

Hariyano. 2008. Pembesaran Bubara (Caranx sp) di Keramba Jaring Apung. Balai Budidaya Laut Ambon. Laporan Tahunan 2008. Direktorat Jenderal Perikanan Budidaya. Kementerian Kelautan dan Perikanan. Jakarta.

Hariyano. 2009. Pembesaran Bubara (Caranx sp) di Keramba Jaring Apung. Balai Budidaya Laut Ambon. Laporan Tahunan 2009. Direktorat Jenderal Perikanan Budidaya. Kementerian Kelautan dan Perikanan. Jakarta.

Hariyano, E.A. Basir, W. Nuraini. 2008. Potensi Pengembangan Pembesaran Ikan Famili Carangidae di Keramba Jaring Apung Teluk Ambon Bagian Dalam. Makalah. Departemen Kelautan dan Perikanan Direktorat Jenderal
Perikanan Budidaya Balai Budidaya Laut Ambon.

Karimah, U., I. Samidjan, Pinandoyo. 2018. Performa Pertumbuhan dan Kelulushidupan Ikan Nila Gift (Oreochromis niloticus) yang Diberi Jumlah Pakan yang Berbeda. Journal of Aquaculture Management and Technology 7(1): 128-135.

Iskandar, R. \& Elrifadah. 2015. Pertumbuhan dan Efisiensi Pakan Ikan Nila (Oreochromis niloticus) yang Diberi Pakan Buatan Berbasis Kiambang. Ziraa'ah 40(1): 18-24.

Ismi, S. 2017. Pengaruh Penggantian Oksigen pada Transportasi Benih Kerapu Dengan Sistem Tertutup. Jurnal Ilmu dan Teknologi Kelautan Tropis 9(1): 385-391.

Karimah, U., I. Samidjan, Pinandoyo. 2018. Performa Pertumbuhan dan Keluluhidupan Ikan Nila Gift (Oreochromis niloticus) yang Diberi Jumlah Pakan yang Berbeda. Journal of Aquaculture Management and Technology 7(1): 128-135.

Kementerian Kelautan dan Perikanan RI. 2020. Target dan Program Prioritas Perikanan Budidaya Tahun 2021. https://kkp.go.id/artikel/25859-target-danprogam-prioritas-perikanan-budidaya-tahun2021. Diakses 11 Januari 2021.

Lumi, K.W., U.N.W.J. Rembet, S. Darwisito. 2019. Kajian Ekologi-Ekonomi Budidaya Ikan Kuwe (Caranx sp) di Kecamatan Lembeh Utara Kota Bitung Provinsi Sulawesi Utara. Jurnal Ilmiah Platax 7(1): 121-133.

Mayunar. 1999. Produktivitass Beberapa Jenis Ikan Laut yang Dibudidaya Dalam Keramba Jaring Apung. Oseana XXIV (2): 21-26.

Minjoyo, H., A. Prihaningrum, Istikomah. 2007. Pembesaran Bawal Bintang Trachinotus blochii, Lacepede dengan Padat Tebar Berbeda di Keramba Jaring Apung. BBPBL Lampung.

Nugroho. R., M.F. Sukadi, G.H. Huwoyon. 2012. Beberapa Jenis Ikan Lokal yang Potensial Untuk Budidaya: Domestikasi, Teknologi Pembenihan, dan Pengolahan Kesehatan Lingkungan Budidaya. Media Akuakultur 7(1): 52-57.

Raharjo, E.I., Rachimi, A. Riduan. 2016. Pengaruh Padat Tebar yang Berbeda Terhadap Pertumbuhan dan Kelangsungan Hidup Benih Ikan Biawan (Helostoma temmincki). Jurnal Ruaya 4(1): 45-53.

Rifai, U \& D.A. Horhoruw. 2016. Application of Commodities Diversification System for Grouper and Giant Trevally (Caranx sp) as 
Development Strategy Efforts in Fish Farming. 2016. Buku Prosiding I IndoaquaAPA. 1-14 hal.

Santoso, L. \& H. Agusmansyah. 2011. Pengaruh Substitusi Teoung Kedelai Dengan Tepung Biji Karet pada Pakan Buatan terhadap Pertumbuhan ikan Bawal Air Tawar (Colossoma macropomum). Berkala Perikanan Terubuk 39(2): 41-50.

Saputra, I., W.K.A. Putra, T. Yulianto. 2018. Tingkat Konversi dan Efisiensi Pakan Benih Ikan Bawal Bintang (Trachinotus blochii) Dengan Frekuensi Pemberian Berbeda. Journal of Aquaculture Science 3(2): 170-181.

Syafei, L.S. 2017. Keanekaragaman Hayati dan Konservasi Ikan Air Tawar. Jurnal Penyuluhan Kelautan dan Perikanan Indonesia 11(1): 48-62.
Yatiningsih, R., H. Boesono, Sardiyatmo. 2018. Analisis Perubahan Salinitas Terhadap Tingkat Kematian dan Tingkah Laku Ikan Nilai Merah (Oreachromis niloticus) Sebagai Pengganti Umpan Hidup Pada Penangkapan Cakalang. Journal of Fisheries Resources Utilization Management and Technology 7(1): 1-10.

Zakaria, H. M., Suminto, I. Samidjan. 2018. Pengaruh Penambahan Probiotik pada Pakan yang Memanfaatkan Sumber Protein dari Tepung Telur Ayam Afkir Terhadap Pertumbuhan dan Kelulushidupan Nila (Oreochromis niloticus). Journal of Aquaculture Management and Technology 7(1): 71-79.

Zulfadhli \& R. Fadhilah. 2019. Domestikasi Ikan Bileh (Rasbora sp) Asal Perairan Aceh Barat dalam Wadah Budidaya Berbeda. Jurnal Perikanan Tropis 6(2): 101-107. 